Article

\title{
Structure and Genetic Diversity of Nine Important Landraces of Capsicum Species Cultivated in the Yucatan Peninsula, Mexico
}

\author{
Lucero del C. López Castilla ${ }^{1}$, René Garruña Hernández ${ }^{2}$, Crescencio de la Cruz Castillo Aguilar ${ }^{3}$, \\ Aida Martínez-Hernández ${ }^{3}$, Matilde Margarita Ortiz-García ${ }^{4}$ and Rubén H. Andueza-Noh ${ }^{2, *(D)}$ \\ 1 Instituto Tecnológico de Conkal, Yucatán, Avenida Tecnológico S/N Conkal, Conckal C.P. 97345, \\ Yucatán, Mexico \\ 2 CONACYT-Instituto Tecnológico de Conkal, Yucatan, Avenida Tecnológico S/N Conkal, Conckal C.P. 97345, \\ Yucatán, Mexico \\ 3 Colegio de Posgraduados, Campus Campeche, Carretera Haltún-Edzná km 17.5, Sihochac, \\ Champotón C.P. 24450, Campeche, Mexico \\ 4 Centro de Investigación Científica de Yucatán, A. C. (CICY), Mérida C.P. 97205, Yucatán, Mexico \\ * Correspondence: r_andueza81@hotmail.com
}

Received: 28 May 2019; Accepted: 12 July 2019; Published: 14 July 2019

\begin{abstract}
Mexico has a wealth of Capsicum species, which has led to the development of a large number of chili pepper landraces. A great wealth of Capsicum germplasm can be found in southern Mexico in the Yucatan Peninsula, an important area of diversification of Capsicum annuum. Specifically, in the western Yucatan Peninsula, three of the five domesticated species of Capsicum (C. annuum, C. chinense and C. frutescens) have been reported. However, information on their genetic diversity, conservation status and potential use is lacking. To generate useful information toward the sustainable use, management and conservation of these species, we evaluated the structure, diversity and genetic relationships of nine accessions of Capsicum spp., of major importance cultivated in the western Yucatan Peninsula using 42 ISSR loci. The results indicated that these accessions consisted of three genetic groups that were defined by the respective species of each accession. The level of genetic diversity was moderate and distributed mainly among accessions. The ISSR markers detected a high level of polymorphism and allowed the genetic differentiation of the C. annuum complex. The results indicated that the accessions collected in the western Yucatan Peninsula constitute a valuable genetic resource that can be used in genetic improvement and conservation programs.
\end{abstract}

Keywords: plant genetic resources; Capsicum annuum; Capsicum chinense; genetic relationships; ISSR markers; on-farm varieties; Yucatan Peninsula

\section{Introduction}

The genus Capsicum is native to Latin America and the Caribbean and includes 38 species, of which Capsicum annuum L., Capsicum chinense Jaqc., Capsicum frutescens L., Capsicum pubescens Ruiz \& Pavon and Capsicum baccatum L., have been domesticated [1]. These species are believed to have come from three genetic lineages; C. pubescens and C. baccatum each represent a different lineage, and the third lineage is a genetic complex comprising C. annuum, C. chinense and C. frutescens [2]. C. annuum is the most widely grown species worldwide, and its center of domestication and genetic diversity is in Mexico [3]. In addition to C. annuum, numerous cultivated chili peppers and wild populations of Capsicum species in Mexico represent a vast reservoir of morphological and genetic diversity that can be used for genetic improvement of Capsicum species [4,5]. 
In Mexico, Aguilar-Meléndez [6] considered the Yucatan Peninsula (Yucatán, Campeche and Quintana Roo states) as an important region of domestication and diversification of Capsicum annuum. Despite this importance, very few studies have focused on the genetic diversity of Capsicum throughout the entire Peninsula; instead, the central area of the Yucatan Peninsula, that is, Yucatan state [7-9], has received all the attention. Thus, the total diversity present in the entire Yucatan Peninsula, inclusive of the other two states (Campeche and Quintana Roo states), is still unknown.

In Campeche State, in the western part of the Yucatan Peninsula, the presence of the C. annuum, C. frutescens and C. chinense species has been reported [10]; however, until now, the genetic diversity of these species has not been studied. Previous studies on the genetic diversity of Capsicum present in the Yucatan Peninsula have been based solely on phenotypic traits, which are influenced by the environment, thus complicating the evaluations [11]. As DNA-based technology has revolutionized the evaluation of genetic diversity through the use of molecular markers [12], intersimple sequence repeat (ISSR) markers have proven to be very useful for characterizing germplasm and estimating inter and intraspecific genetic diversity in Capsicum species [9,13-15]. ISSRs are dominant markers, based on the amplification of DNA through the use of a single primer composed of a microsatellite (SSR) sequence, that allows the detection of polymorphisms without prior knowledge of the DNA sequence [16]. Hence, the objective of the present study was to evaluate the structure and genetic diversity of new landraces of Capsicum spp., collected in the western region of the Yucatan Peninsula.

\section{Materials and Methods}

\subsection{Plant Material}

Chili pepper landraces were collected in four Mayan areas (Calkiní, Campeche, Escárcega, and Palizada) of Campeche state in western Yucatan Peninsula, where farmers are still growing landraces of chili pepper within their traditional agricultural system. The germplasm collection included nine accessions of Capsicum spp. (Figure 1). Seven accessions belonging to C. annuum (local names: Bobo, Bolita, Dulce, Verde, Xcat'ik1, Xcat'ik2 and Maax), one accession belonging to $C$. frutescens (local name: Pico paloma) and one accession belonging to C. chinense (local name: Rosita). We included only these nine chili pepper landraces because they are the most representative of the region and the most cultivated and economically important in the Yucatan Peninsula.

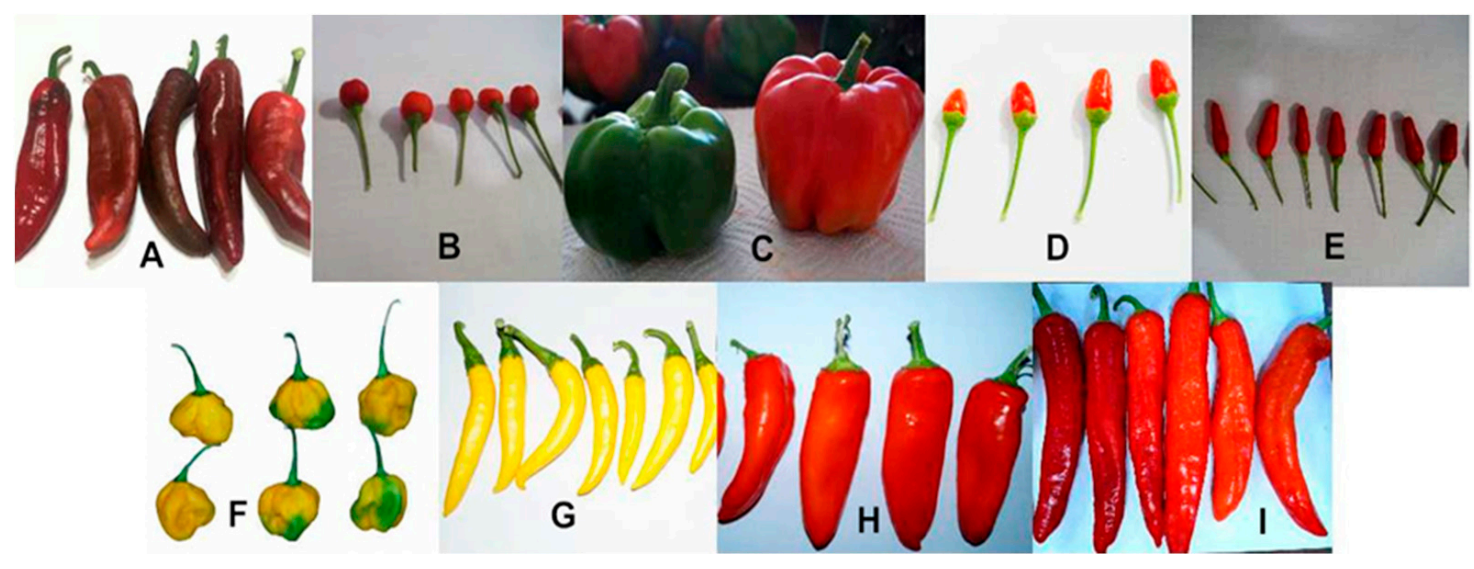

Figure 1. Accessions of Capsicum spp. evaluated in the study: (A) C. annuum (local name: bobo); (B) C. annuum (local name: bolita); (C) C. annuum (local name: dulce); (D) C. annuum var. aviculare (local name: maax); (E) C. frutescens (local name: pico paloma); (F) C. chinense (local name: rosita); (G) C. annuum (local name: verde); (H) C. annuum (local name: ecotipo Xcat'ic 1); (I) C. annuum (local name: Xcat'ic 2). 


\subsection{DNA Extraction and ISSR Amplification}

Twenty seeds of each accession were germinated in a greenhouse at the Colegio de Posgraduados campus Campeche, Mexico. Because some plants died and others had problems with pests or diseases, genomic DNA was extracted from young leaves of eight individual plants of each accession using the $\mathrm{CTAB}$ protocol [17] modified as follows: $2.5 \mathrm{~g}$ of frozen and pulverized leaf tissue was incubated for $40 \mathrm{~min}$ at $65^{\circ} \mathrm{C}$ in $25 \mathrm{~mL}$ of CTAB buffer (Tris $\mathrm{HCl} \mathrm{pH} 8.0100 \mathrm{mM}, \mathrm{NaCl} 1.4 \mathrm{M}$, EDTA $50 \mathrm{mM}$, $\beta$-mercaptoethanol 0.5\%, CTAB 1.5\%, PVP 40\% pH 5.0). RNAse $(25 \mu \mathrm{g} / \mathrm{mL})$ was then added and the mixture incubated for $20 \mathrm{~min}$ with continuous rotary shaking. Two extraction steps with $10 \mathrm{~mL}$ of chloroform-isoamyl alcohol (24:1) were done, followed by DNA precipitation with 0.8 volumes of isopropanol at $25^{\circ} \mathrm{C}$ for $1 \mathrm{~h}$. The DNA pellet was collected by centrifugation at $13,000 \mathrm{rpm}$ for $10 \mathrm{~min}$ at $15{ }^{\circ} \mathrm{C}$, then washed twice with $70 \%$ ethanol and suspended with $500 \mu \mathrm{L}$ of sterile deionized water. The quality of DNA was verified by electrophoresis in $1 \%$ agarose with $0.5 \times$ Tris-borate-EDTA buffer (0.5× TBE: $100 \mathrm{mM}$ Tris-borate, pH 8.0, 2 mM EDTA) and staining with Uview $6 \times$ loading dye (BioRad, Hercules, CA, USA).

For PCR amplification of 10 ISSR primers that have previously yielded good amplification and high levels of polymorphism for Capsicum spp. $[13,18]$, four were selected that yielded good amplification and high levels of polymorphism for all accessions of Capsicum spp., evaluated, after a preliminary test [CTC $(\mathrm{GT})_{8},(\mathrm{GC})_{2} \mathrm{CGCCGCCGCC}, \mathrm{TACA}(\mathrm{GCA})_{3} \mathrm{G}$ and 823]. The PCRs were carried out using the ISSR method described by Dias et al. [13], Thul et al. [19] and Yao et al. [18], in a total volume of 20 $\mu \mathrm{L}$ containing $10 \mu \mathrm{L}$ of iTaq Universal SYBR Green Supermix (Bio-Rad), $2 \mu \mathrm{L}$ of ISSR primer, $1 \mu \mathrm{L}$ of template DNA ( $50 \mathrm{ng} /$ reaction), and $7 \mu \mathrm{L}$ of ultra-pure water. The conditions for amplification in a thermal cycler C1000 Touch (BioRad) were $4 \mathrm{~min}$ at $94{ }^{\circ} \mathrm{C}$ for initial denaturing, 35 cycles of $2 \mathrm{~min}$ at 94 ${ }^{\circ} \mathrm{C}, 1.5 \mathrm{~min}$ at 52 or $54{ }^{\circ} \mathrm{C}$ (depending on the primer used) for annealing, $2 \mathrm{~min}$ at $72{ }^{\circ} \mathrm{C}$, and a final extension of $5 \mathrm{~min}$ at $72{ }^{\circ} \mathrm{C}$. The products were separated by electrophoresis in $1.5 \%$ agarose gel with $1 \times$ TBE buffer at $110 \mathrm{~V}$ for $45 \mathrm{~min}$ and stained with Uview $6 \times$ loading dye (BioRad). A $1 \mathrm{~kb}$ molecular marker standard was included in each gel, and bands were visualized using the Gel Doc EZ Imager program (BioRad). For interpreting the results, each ISSR band was considered as an independent locus, and polymorphic bands were scored as absent (0) or present (1) for all samples. Only clear and reproducible bands were used for the analysis.

\subsection{Data Analysis}

\subsubsection{Genetic Structure Analysis}

The genetic structure was analyzed using two methods. First, the data were analyzed using an individual assignment test with STRUCTURE v. 2.3.4 software [20], which uses a Bayesian clustering approach to assign individual genotypes to a predefined number of populations $(K)$, each one characterized by a set of allele frequencies at each locus. To infer the number of $K$ populations, we used the ancestry admixture model with correlated allele frequencies. For each $K$ value ( $K=2$ to 9), 10 independent simulations were evaluated. To obtain reliable data, each simulation consisted of a burn-in period of 10,000 replications and a run length of 100,000 Markov Chain Monte Carlo (MCMC) steps. The optimal value of $K$ was determined according to Evanno et al. [21] using the program Structure Harvester v. 0.6.93 [22]. Finally, ancestry graphs for the optimum value of $K$ were generated using STRUCTURE v. 2.3.4 software [20]. Second, data were analyzed using an analysis of molecular variance (AMOVA) in GenAlEx 6.5 software [23] considering two levels: between accessions and within accessions.

\subsubsection{Genetic Relationship Analysis}

The genetic relationships among different Capsicum spp. landraces were analyzed with a UPGMA (unweighted pair group method with arithmetic mean) dendrogram using the Dice similarity coefficient. The tree topology was evaluated with 1000 bootstrap replicates using the PAST program [24]. To 
support the results obtained with the UPGMA, a principal coordinate analysis (PCoA) was performed with GenAlEx 6.503 [23].

\subsubsection{Genetic Diversity Analysis}

Genetic diversity was evaluated at two levels: (1) landraces and (2) observed groups through allelic richness indices: percentage of polymorphic loci $(\% \mathrm{P})$; observed number of alleles $(\mathrm{Na})$; effective number of alleles (Ne); and the better estimators of genetic diversity for analyzing dominant markers [25,26], the Shannon-Weaver diversity index $(I)$ and average heterozygosity $\left(H_{\text {Bay }}\right)$, with a Bayesian approach [27]. The allelic richness indices and Shannon-Weaver diversity index were obtained using the POPGENE $v$. 1.31 program [28]. The average heterozygosity $\left(H_{\text {Bay }}\right)$ was calculated using AFLPSURV v. 1.0 [29].

\section{Results}

\subsection{Genetic Structure of Capsicum Species Landraces Cultivated in the Yucatan Peninsula}

The genetic structure of all accessions was analyzed without any prior classification to identify the optimal number of populations $(K)$. The method of Evanno et al. [21] showed a clear peak at the optimum value of $K=3$ and a second peak at $K=6$ for the nine accessions analyzed, indicating the existence of three genetically distinct groups and sub-clustering within the three main groups (Figure 2).

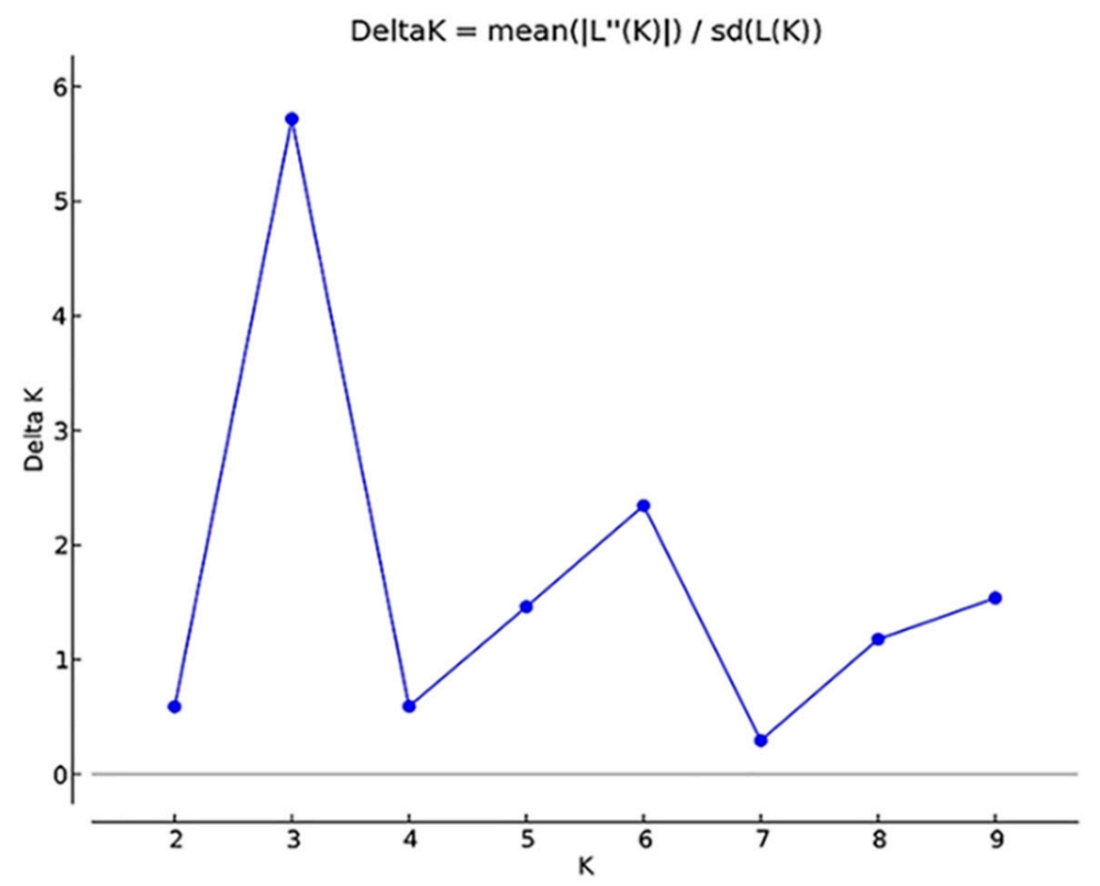

Figure 2. Graph of $\Delta K$ values to estimate the number of groups among nine chili pepper landraces cultivated in the western Yucatan Peninsula using $\Delta K$ values from 2 to 9.

Figure 3 shows the ancestry coefficients of the 72 samples analyzed for the nine accessions studied; three genetically differentiated groups and six subgroups within the three main groups can be observed, with ancestry coefficients close to $100 \%$ in each group. Accessions Bobo, Dulce, Maax, Verde, Xcat'ik1, and Xcat'ik 2 formed the first group with three subgroups (1A formed by Bobo and Dulce, $1 \mathrm{~B}$ formed by Maax and Xcat'ik2, and 1C formed by Verde and Xcat'ik1); Bolita and Pico Paloma accessions formed a second group with two subgroups (2A and 2B); and Rosita formed a third group. 


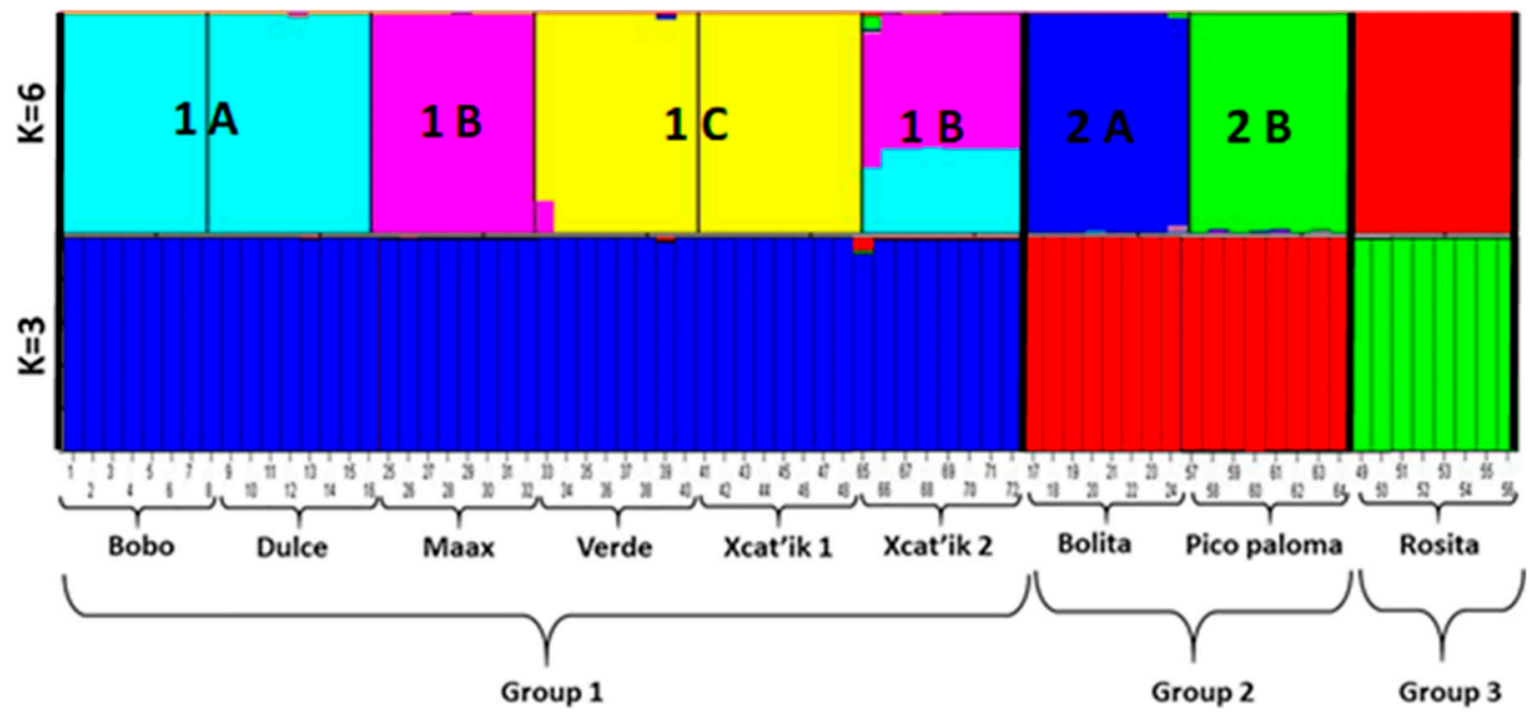

Figure 3. Proportion of estimated ancestry of nine chili pepper landraces (Capsicum spp.) showing three genetic groups determined by the Structure program with $K=3$ and $K=6$. Each individual is represented by a vertical line; (1A), (1B) and (1C) are subgroups of group $1 ;(\mathbf{2 A})$ and (2B) are subgroups of group 2. Individuals are grouped by accession.

The AMOVA results indicated that $92 \%$ of the total variation was distributed among the accessions and only $8 \%$ within the accessions (Table 1), indicating high genetic differentiation among the accessions analyzed.

Table 1. Analysis of molecular variance (AMOVA) of ISSR molecular markers in nine chili pepper landraces (Capsicum spp.) cultivated in the Yucatan Peninsula.

\begin{tabular}{ccccc}
\hline Source of Variation & Df & SS & Variance Component & Variation Percentage \\
\hline Among accessions & 8 & 416.972 & 6.449 & 92 \\
Within accessions & 63 & 33.375 & 0.530 & 8 \\
Total & 71 & 450.347 & 6.979 & 100 \\
\hline
\end{tabular}

$\mathrm{DF}=$ degrees of freedom; $\mathrm{SS}=$ sum of squares.

\subsection{Genetic Relationships}

The UPGMA tree (Figure 4) grouped the nine accessions into three major groups (identified by capital letters A, B and C), showing a general grouping based mainly on the genetic constitution of the species to which each accession belongs. Group A consisted of the Rosita accession (Capsicum chinense Jacq.), which was the most divergent of the accessions. Group B consisted of the Bolita and Pico Paloma accessions, which belong to different species (Capsicum annuum and Capsicum frutescens, respectively); both were collected in the same geographical region and could be the result of interspecific crossing, which could explain the high similarity between them. Group C comprised six accessions of Capsicum annuum, with two subgroups. Subgroup C1 consisted of accessions Xcat'ik2, Dulce and Bobo, and subgroup C2 consisted of accessions Verde, Xcat'ik1 and Maax. In this way, the first group included the accessions of the third group previously defined in the Structure results, the second group included the accessions of the second group in the Structure results, and the third group included the accessions of the first group in the Structure results.

The PCoA indicated that the first two principal coordinates explained $64.63 \%$ of the cumulative total variation. The first principal coordinate (PCoA 1) explained $42.82 \%$ of the variation, while the second PCoA 2 explained 21.81\% (Figure 5). The results obtained in the PCoA support the UPGMA dendogram (Figure 4 ) by generating the formation of three main groups named A, B and C, with $100 \%$ similarity to the topology of the UPGMA. Group A consisted of the Rosita Accessions. Group B 
comprised two accessions (Pico Paloma and Bolita) with two subgroups (B1 and B2). Group C consisted of accessions Xcat'ik2, Dulce, Bobo, Verde, Xcat'ik1 and Maax with two subgroups (C1 and C2).

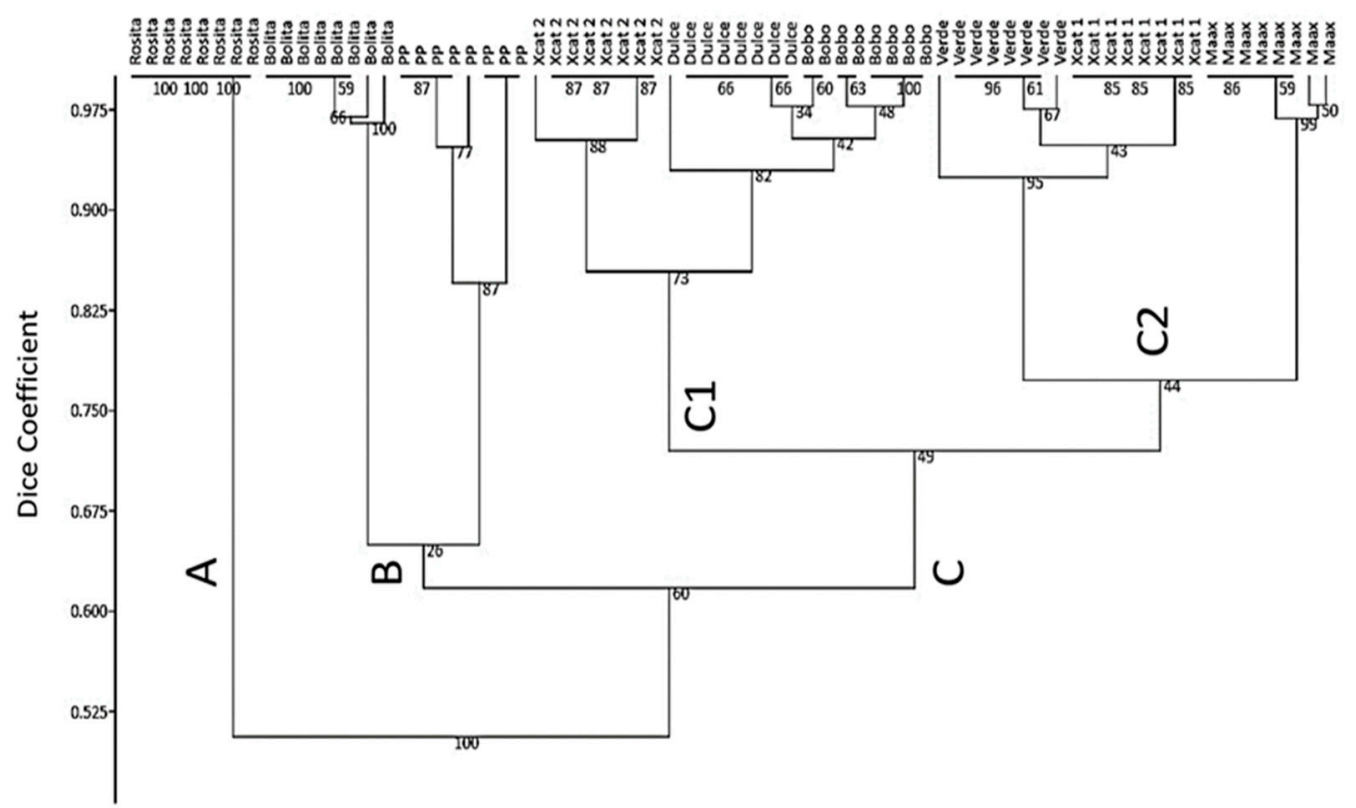

Figure 4. UPGMA dendrogram showing genetic relationships among nine accessions of chili pepper landraces cultivated in the western Yucatan Peninsula, Mexico. Numbers at the branches indicate bootstrap support. A, B and C major groups. C1 and C2 subgroups within Group C.

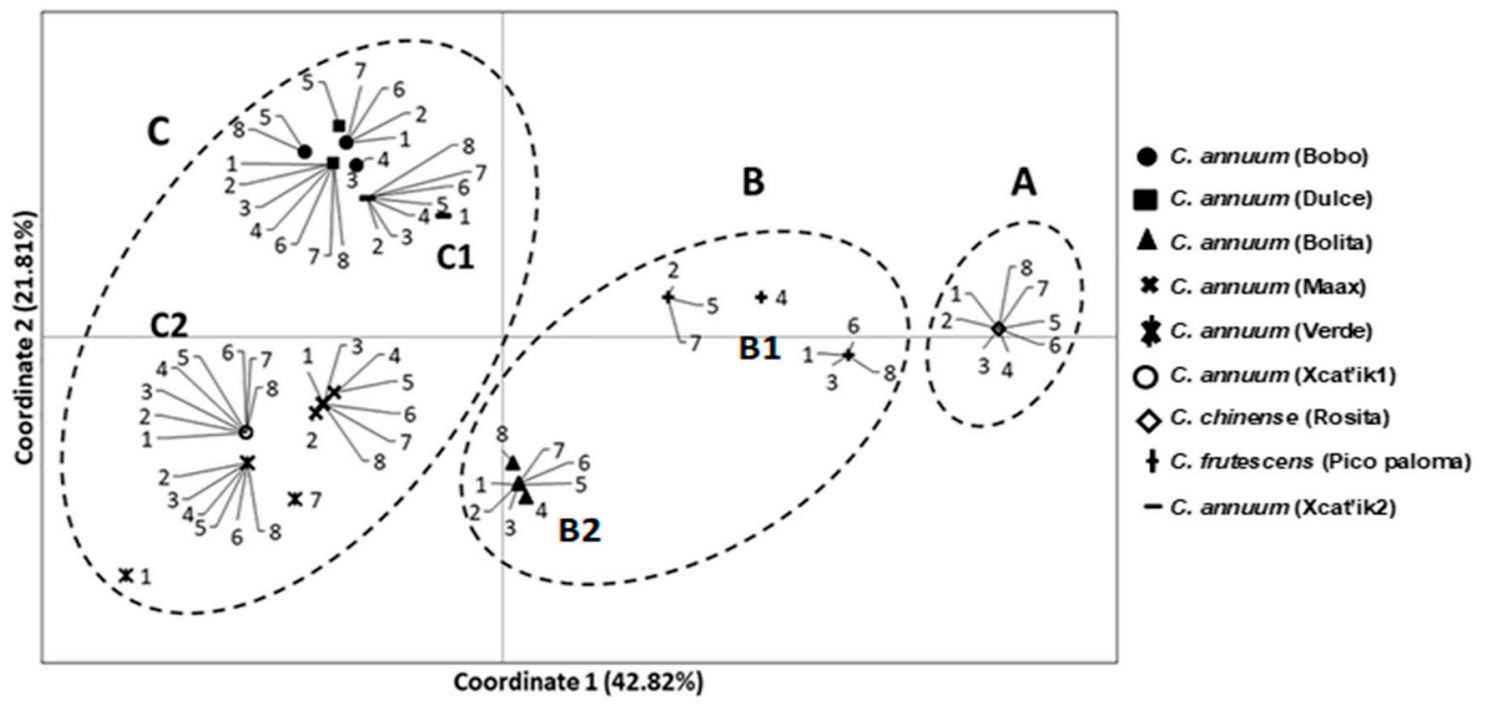

Figure 5. Principal coordinate analysis ( $\mathrm{PCoA})$ of the nine chili pepper landraces cultivated in the western Yucatan Peninsula, Mexico. Numbers indicate the number of individuals for each accession. A, B and C major groups. B1 and B2 subgroups within Group B; C1 and B2 subgroups within Group C.

\subsection{Genetic Diversity}

The four ISSR primers generated a total of 42 loci; 37 were polymorphic and five monomorphic for all samples. The genetic diversity was analyzed at the accession level and at genetic group level as indicated by the Bayesian approach. At the accession level (Table 2), Pico Paloma had the highest percentage of polymorphic loci and genetic diversity value $\left(\% P=14.29\right.$ and $\left.I=0.089, H_{\text {Bay }}=0.077\right)$, while in Xcat'ik1 and Rosita, the markers did not allow the presence of polymorphic alleles; therefore, 
its genetic diversity was the lowest. Total level a high percentage of polymorphic loci $(\% P=88)$ and moderate genetic diversity were observed $\left(I=0.44, H_{\text {Bay }}=0.0176\right)$.

Table 2. Estimators of genetic diversity at the accession level in nine chili peppers landraces (Capsicum spp.) cultivated in the Yucatan Peninsula.

\begin{tabular}{cccccc}
\hline Accession & $\mathbf{\%} P$ & $\mathbf{N a}$ & $\mathbf{N e}$ & $\boldsymbol{I}$ & $\boldsymbol{H}_{\text {Bay }}$ \\
\hline Bobo & 4.76 & 1.0476 & 1.0476 & 0.0330 & 0.02009 \\
Dulce & 7.14 & 1.0714 & 1.0601 & 0.0464 & 0.01758 \\
Maax & 4.76 & 1.0476 & 1.0271 & 0.0222 & 0.01590 \\
Verde & 2.38 & 1.0238 & 1.0211 & 0.0158 & 0.00666 \\
Xcat'ik1 & 0.00 & 1.000 & 1.000 & 0.000 & 0.00000 \\
Xcat'ik2 & 4.76 & 1.0476 & 1.0401 & 0.0309 & 0.01172 \\
Bolita & 4.76 & 1.0476 & 1.0401 & 0.0309 & 0.01172 \\
Pico Paloma & 14.29 & 1.1429 & 1.1100 & 0.0887 & 0.07701 \\
Rosita & 0.00 & 1.000 & 1.000 & 0.000 & 0.00000 \\
Total & 88.10 & 1.8810 & 1.5107 & 0.4402 & 0.0176 \\
\hline
\end{tabular}

$\% P$ : percentage of polymorphic loci; $\mathrm{Na}$ : observed number of alleles; $\mathrm{Ne}$ : effective number of alleles; I: Shannon-Weaver index; HBay: average heterozygosity as proposed by Zhivotovsky [27]. Note: the number of samples for all accessions was eight.

At the genetic group level (Table 3), group one formed by the species of $C$. annuum (accessions Bobo, Dulce, Maax, Verde, Xcat'ik1 and Xcat'ik2) had the highest percentage of polymorphic loci ( $\% P$ $=54.76)$ and genetic diversity $\left(I=0.29\right.$ y $\left.H_{\text {Bay }}=0.19\right)$. The second group with species of Capsicum annuum and Capsicum frutescens (accessions Bolita and Pico Paloma) had $\% P=38, I=0.23$ and $H_{\text {Bay }}$ $=0.17$, and third group with only one species, Capsicum chinense (accession Rosita), had the lowest genetic diversity.

Table 3. Estimators of genetic diversity observed at group level in nine chili peppers landraces (Capsicum spp.) cultivated in the Yucatan Peninsula.

\begin{tabular}{ccccccc}
\hline Group & No. Samples & $\mathbf{\%} \boldsymbol{P}$ & $\mathbf{N a}$ & $\mathbf{N e}$ & $\boldsymbol{I}$ & $\boldsymbol{H}_{\text {Bay }}$ \\
\hline 1 & 48 & 54.76 & 1.5476 & 1.3614 & 0.2935 & 0.19991 \\
2 & 16 & 38.10 & 1.3810 & 1.3078 & 0.2376 & 0.17590 \\
3 & 8 & 0.00 & 1.000 & 1.000 & 0.000 & 0.00000 \\
Total & 72 & 88.10 & 1.8810 & 1.5107 & 0.4402 & 0.0179 \\
\hline
\end{tabular}

$\% P$ : percentage of polymorphic loci; $\mathrm{Na}$ : observed number of alleles; $\mathrm{Ne}$ : effective number of alleles; I: Shannon-Weaver index; $H_{\text {Bay }}$ : average heterozygosity proposed by Zhivotovsky [27].

\section{Discussion}

This study is the first analysis of the structure and genetic diversity of chilli pepper landraces germplasm from the western region of the Yucatan Peninsula. The results indicated that the genetic structure of the landraces was integrated into three main genetic groups. The low percentage of intra-accessions variation determined by the AMOVA is consistent with the results of Aguilar-Meléndez et al. [6] and can be attributed to the accessions belonging to different species; therefore, the greatest variation is expected to be among accessions. This result indicates that genetic structure is high at the accession level and supports the three groups observed in the Bayesian analysis (Figure 3). The high levels of genetic structure found in the chili pepper landraces might be due to particular biological characteristics of the species such as the predominantly autogamous reproductive system, short life cycle, and dispersal ability of pollen; or due to inbreeding [30,31], all aspects that may promote isolation by distance and interspecific variation as a result of mutation, genetic drift and the selection pressure exerted by farmers for different growing conditions. These results are similar to those of Albrecht et al. [32] in a study of varieties of C. baccatum (var. baccatum, var. pendulum, var. praetermissum, var. umbilicatum); the greatest variation occurred among the populations $(75 \%)$, not within populations 
$(25 \%)$, indicating that although the populations are of the same species, variation can be high among the populations. On the other hand, in a study of the diversity and genetic structure of wild populations of Capsicum annuum var. glabriusculum and cultivated populations of $C$. annuum var. annuum in northeastern Mexico, Hernández et al. [33] and Oyama et al. [34] found that genetic variation was equally distributed between and within the accessions.

\subsection{Genetic Relationships between Nine Accessions of Capsicum Species Landraces from the Yucatan Peninsula}

The results of the UPGMA and PCoA showed a general grouping according to the three groups observed in the Structure results. Although C. annuum, C. chinense and C. frutescens belong to the same genetic complex, the results generated by the dendogram and PCoA (Figures 4 and 5) in this study demonstrate that the three species can be differentiated. Intraspecific genetic differentiation among seven species of Capsicum, including the C. annuum complex, was also reported by Jarret [35] using eight chloroplast DNA introns (cpDNA). However, Yumnam et al. [36], in a study of landraces of Capsicum species in northeastern India, using SSR and SNP markers did not find any genetic differentiation between $C$. annuum and $C$. chinense species and suggested the need to use a specific marker for the species. The discrepancies observed between the results of Yumnam et al. [36] and the results of the present study with respect to the level of differentiation between the species $C$. annuum and $C$. chinense can be explained by the use of different markers. Rai et al. [37] suggested that the lack of polymorphism for SSRs markers between genotypes of Capsicum may limit their application for Capsicum. Regardless of the type of marker used, the level of differentiation observed in this study can also be attributed to the degree of domestication of the species under study, as reported by Camacho-Peréz et al. [38] and Martínez-Castillo et al. [39] for cultivated landraces of lima bean; ISSR markers have a higher level of polymorphism compared to SSR markers in cultivated varieties. The formation of the subgroup that contains the landraces Bobo, Dulce and Xcat'ik2 strongly supports the suggestion of González et al. [40] that Bobo is a progeny from a spontaneous cross between Xcat'ik and Dulce landraces and validates the existence of natural crosses between Capsicum species cultivated in sympatry [37].

Mexico is the center of domestication and diversity for C. annuum, and the Yucatan Peninsula is an important area of diversification of this species, which may explain that the greater number of accessions of $C$. annuum compared to the other species in this study. The Rosita accessions (C. chinense), despite having separated from the rest, were genetically closer to Pico Paloma accession (C. frutescens) than to the rest of the accessions of $C$. annuum (Figures 4 and 5). Eshbaugh et al. [2] suggested that C. frutescens is a primitive relative and predecessor of $C$. chinense; however, Baral and Bosland [41] determined that these species represent two isolated, distinct species. Despite this, several studies indicate a close relationship between C. chinense and C. frutescens [14,19,42]. Unlike the rest of the species, C. chinense does not have wild forms in Mexico; its origin and diversification center is believed to be the Amazon region [2] and to have been introduced to the Yucatan Peninsula from Cuba [40,43]. Similarly, C. frutescens originated in South America [44], but unlike C. chinense, wild and domesticated forms of $C$. frutescens can be found throughout Mexico.

\subsection{Genetic Diversity of Nine Accessions of Capsicum Species from Yucatan Peninsula}

Genetic diversity at the accession level was low, [6,32]. This low level of genetic diversity may have been influenced by the autogamous mating system of the species. Independent of the mating system, these patterns of genetic diversity may also be due to the lower variation found in ex-situ germplasm collections compared to in-situ collections [34] or due to the domestication process, which leads to a reduction in genetic diversity, known as a bottleneck in crop species [45]. It is important to note that the Rosita and Xcat'ik1 accessions have lower levels of polymorphism and genetic diversity ( $\% P=0.00, I=0.00$ and $H_{B a y}=0.00$ ). This result may be due to the small number of individuals studied, which may indicate that the sampling was not representative of the genetic diversity present in the accessions or that the individuals sampled were monomorphic for the primers evaluated, or strong selection pressure might have been exerted on these two accessions by humans. 
At the genetic group level, group 1 presented the greatest genetic diversity, perhaps because it included the most accessions (Bobo, Dulce, Maax, Verde, Xcat'ik1, and Xcat'ik2) of all the groups. However, despite having fewer accessions (two accessions: Bolita and Pico Paloma), group two had a genetic diversity value similar to that of group one, indicating that the accessions that formed this group present high levels of genetic diversity, and that the genetic diversity found for all accessions evaluated was high. This result is similar to that found by Lopéz-Espinoza et al. [9] for 60 landraces of Capsicum chinense from southern Mexico using three ISSR primers and were higher than those by Hanáček et al. [46] who reported an average polymorphism of 0.33 among 41 accessions of $C$. annuum.

\section{Conclusions}

The results obtained in this work contribute to our knowledge regarding the genetic diversity in Capsicum species in the Yucatan Peninsula by including for the first time accessions of chili pepper landraces collected in regions that had not been explored in previous studies. The results revealed that the accessions in the western Yucatan Peninsula have moderate levels of genetic diversity. The genetic structure of the accessions studied was high and consisted mainly of three genetic groups defined by the species to which each landrace belongs and not by geographical origin. Genetic diversity was distributed mainly among accessions. At the accession level, Pico Paloma had the highest level of genetic diversity, and Rosita had the lowest, because the selection pressure on this accession has been more intense and may thus be generating a bottleneck by domestication, putting it at risk of genetic erosion. The ISSR markers detected a high level of polymorphism and revealed the genetic differentiation of the $C$. annuum complex. Our results also indicate that the accessions collected in the western Yucatan (Calkiní, Campeche, Escárcega and Palizada) constitute a valuable genetic resource that can be used for genetic improvement and conservation programs both ex situ and in situ. These results will serve as a foundation for further studies to obtain more detailed information on the degree of domestication of the landraces of Capsicum in the Yucatan Peninsula.

Author Contributions: Conceptualization, L.d.C.L.C., R.G.H. and R.H.A.-N.; Formal analysis, L.d.C.L.C., R.G.H. and R.H.A.-N.; Investigation, R.H.A.-N.; Methodology, L.d.C.L.C., R.G.H., M.M.O.-G. and R.H.A.-N.; Writing-original draft, L.d.C.L.C., R.G.H. and R.H.A.-N.; Writing-review \& editing, C.d.l.C.C.A. and A.M.H.

Funding: This research was founded by COFUPRO 2016 grant number CC1600003336 and APC was founded by the authors.

Acknowledgments: The first author thanks the Consejo Nacional de Ciencia y Tecnología-Mexico for a postgraduate scholarship (scholarship number: 777796) and to the Laboratory of Molecular Genetics of Tecnológico de Conkal.

Conflicts of Interest: The authors declare that they have no conflict of interest.

\section{References}

1. USDA-ARS. Grin Species Records of Capsicum; National Germplasm Resources Laboratory: Beltsville, MD, USA, 2011.

2. Eshbaugh, W.H. Peppers: History and exploitation of a serendipitous new crop discovery. In New Crops; Janick, J., Simon, J.E., Eds.; Wiley: New York, NY, USA, 1993; pp. 132-139.

3. Kraft, K.H.; Brown, C.H.; Nabhan, G.P.; Luedeling, E.; Luna Ruiz, J.J.; D’Eeckenbrugge, G.C.; Hijmans, R.J.; Gepts, P. Multiple lines of evidence for the origin of domesticated chili pepper, Capsicum annuum, in Mexico. Proc. Natl. Acad. Sci. USA 2014, 111, 6165-6170. [CrossRef]

4. Rodriguéz, J.; Peña, O.B.V.; Gil, M.A.; Martínez, C.B.; Manzano, F.; Salazar, L.L. Rescate in situ de chile “Poblano" en Puebla, México. Rev. Fit. Mex. 2007, 30, 25-32.

5. Hernández, V.S. Los parientes silvestres del chile: Su importancia biológica y cultural. In El chile: Protagonista de la independencia y la revolución; Richterich, K., Ed.; Fundación Herdez: México City, México, 2011; pp. 21-26.

6. Aguilar-Meléndez, A.; Morrell, P.L.; Roose, M.L.; Kim, S.C. Genetic diversity and structure in semiwild and domesticated chiles (Capsicum annuum; Solanaceae) from Mexico. Am. J. Bot. 2009, 96, 1190-1202. [CrossRef] [PubMed] 
7. Latournerie, L.; Chávez, J.L.; Pérez, M.; Hernández, C.F.; Martínez, R.; Arias, L.M.; Castañón, G. Exploración de la diversidad morfológica de chiles regionales en Yaxcabá, Yucatán, México. Agron. Mesoam. 2001, 12, 41-47. [CrossRef]

8. Ix-Nahuat, J.G.; Laournerie-Moreno, L.; Pech-May, A.M.; Pérez-Gutiérrez, A.; Tun-Suárez, J.M.; Ayora-Ricalde, G.; Mijangos-Cortes, J.O.; Castañón-Nájera, G.; López-Vázquez, J.S.; Montes-Hernández, S. Valor agronómico de germoplasma de chile dulce (Capsicum annuum L.) en Yucatán, México. Univ. Y Ciencia 2013, 29, 231-242.

9. López-Espinosa, S.T.; Latournerie-Moreno, L.; Castañón-Nájera, G.; Ruiz-Sánchez, E.; Gómez-Leyva, J.F.; Andueza-Noh, R.H.; Mijangos-Cortés, J.O. Diversidad genética de chile habanero (Capsicum chinense jacq.) mediante ISSR. Rev. Fitotec. Mex. 2018, 41, 227-236.

10. Laborde, C.J.A.; Pozo, O.C. Presente Y Pasado Del Chile En México; INIA-SARH: México City, México, $1982 ;$ p. 80.

11. Rana, M.; Sharma, R.; Sharma, P.; Bhardwaj, S.V.; Sharma, M. Estimation of Genetic Diversity in Capsicum annuum L. Germplasm Using PCR-Based Molecular Markers. Natl. Acad. Sci. Lett. 2014, 37, $295-301$. [CrossRef]

12. Paterson, A.H.; Tanksley, S.D.; Sorrells, M.E. DNA markers in plant improvement. Adv. Agron. 1991, 46, 39-90. [CrossRef]

13. Dias, G.B.; Gomes, V.M.; Moraes, T.M.S.; Zottich, U.P.; Rabelo, G.R.; Carvalho, A.O.; Moulin, M.L.S.; Goncalves, A.; Rodrigues, R.; Da Cunha, M. Characterization of Capsicum species using anatomical and molecular data. Genet. Mol. Res. 2013, 12, 6488-6501. [CrossRef]

14. Carvalho, S.I.C.; Ragassi, C.F.; Bianchetti, L.B.; Reifschneider, F.J.B.; Buso, G.S.C.; Faleiro, F.G. Morphological and genetic relationships between wild and domesticated forms of peppers (Capsicum frutescens L. and C. chinense Jacquin). Genet. Mol. Res. 2014, 13, 7447-7464. [CrossRef]

15. Martinez, A.L.A.; Araújo, J.S.P.; Ragassi, C.F.; Buso, G.S.C.; Reifschneider, F.J.B. Variability among Capsicum baccatum accessions from Góias, Brazil, assessed by morphological traits and molecular markers. Genet. Mol. Res. 2017, 16. [CrossRef] [PubMed]

16. Zietkiewicz, E.; Rafalski, A.; Labuda, D. Genome fingerprinting by simple sequence repeat (SSR)-anchored polymerase chain reaction amplification. Genomics 1994, 20, 176-183. [CrossRef] [PubMed]

17. Doyle, J.; Doyle, J. A rapid procedure for DNA purification from small quantities of fresh leaf tissue. Phytochem. Bull. 1987, 19, 11-15.

18. Yao, H.; Zhao, Y.; Chen, D.F.; Chen, J.K.; Zhou, T.S. ISSR primer screening and preliminary evaluation of genetic diversity in wild populations of Glycyrrhiza Uralensis. Biol. Plant. 2008, 52, 117-120. [CrossRef]

19. Thul, S.T.; Darokar, M.l.1.P.; Shasany, A.K.; Khanuja, A.K. Molecular Profiling for Genetic Variability in Capsicum Species Based on ISSR and RAPD Markers. Mol. Biotechnol. 2012, 51, 137-147. [CrossRef] [PubMed]

20. Pritchard, J.K.; Stephens, M.; Donnelly, P. Inference of population structure using multilocus genotype data. Genetics 2000, 155, 945-959. [PubMed]

21. Evanno, G.; Regnaut, S.; Goudet, J. Detecting the number of clusters of individuals using the software structure: A simulation study. Mol. Ecol. 2005, 14, 2611-2620. [CrossRef]

22. Earl, D.A.; Vonhold, M. Structure harvester: A web site and program for visualizing structure output and implementing the Evanno method. Conserv. Genet. Resour. 2012, 4, 359-361. [CrossRef]

23. Peakall, R.; Smouse, P.E. GenAlEx 6.5: Genetic analysis in excel. Population genetic software for teaching and research-an update. Bioinformatics 2012, 28, 2537-2539. [CrossRef]

24. Hammer, Ø.; Harper, D.A.T.; Ryan, P.D. PAST: Palaeontological statistics software package for education and data analysis. Palaeontol. Electron. 2001, 4, 4-9.

25. Lynch, M.; Milligan, B.G. Analysis of population genetic structure with RAPD markers. Mol. Ecol. 1994, 3, 91-99. [CrossRef] [PubMed]

26. Krauss, S.L. Accurate gene diversity estimates from amplified fragment length polymorphism (AFLP) markers. Mol. Ecol. 2000, 9, 1241-1245. [CrossRef] [PubMed]

27. Zhivotovsky, L. Estimating population structure in diploids with multilocus dominant DNA markers. Mol. Ecol. 1999, 8, 907-913. [CrossRef] [PubMed]

28. Yeh, F.C.; Boyle, T.J. POPGENE v. 1.31. Microsoft Windows-Based Freeware for Population Analysis; University of Alberta and Centre for International Forestry Research; University of Alberta: Edmonton, AB, Canada, 1999.

29. Vekemans, X. AFLP-SURV Version 1.0. Distributed by the Author; Laboratoire de Génétique et Ecologie Végétale, Université Libre de Bruxelles: Brussels, Belgium, 2002. 
30. Hutchinson, J.B. Crop plant evolution: A general discussion. In Essays on Crop Plant Evolution; Hutchinson, J.B., Ed.; Cambridge University Press: Cambridge, UK, 1950; pp. 166-187.

31. Jensen, R.J.; McLeod, M.J.; Eshbaugh, W.H.; Guttman, S.I. Numerical taxonomic analyses of allozymic variation in Capsicum (Solanaceae). Taxon 1979, 28, 315-327. [CrossRef]

32. Albrecht, E.; Zhang, D.; Saftner, R.A.; Stommel, J.R. Genetic diversity and population structure of Capsicum baccatum genetic resources. Genet. Resour. Crop. Evol. 2012, 59, 517-538. [CrossRef]

33. Hernández, V.S.; González, A.R.; Sánchez, P.P.; Casas, A.; Oyama, K. Estructura y diferenciación genética de poblaciones silvestres y domesticadas de chile del noroeste de México analizada con isoenzimas y RAPDS. Rev. Fitotec. Mex. 2006, 29, 25-29.

34. Oyama, K.; Hernández-Verdugo, S.; Sánchez, C.; González-Rodríguez, A.; Sánchez-Peña, P.; Garzón-Tiznado, J.A.; Casas, A. Genetic structure of wild and domesticated populations of Capsicum annuum (Solanaceae) from northwestern Mexico analyzed by RAPDs. Genet. Resour. Crop. Evol. 2006, 53, 553-562. [CrossRef]

35. Jarret, R.L. DNA Barcoding in a Crop Genebank: Resolving the Capsicum annuum species Complex. Open Biol. J. 2008, 1, 35-42. [CrossRef]

36. Yumnam, J.S.; Tyagi, W.; Pandey, A.; Meetei, N.T.; Rai, M. Evaluation of genetic diversity of chilli landraces from North Eastern India based on morphology, SSR markers and the Pun1 locus. Plant. Mol. Biol. Rep. 2012, 30, 1470-1479. [CrossRef]

37. Rai, V.P.; Kumar, R.; Kumar, S.; Rai, A.; Singh, M.; Singh, P.S.; Rai, A.B.; Paliwal, R. Genetic diversity in Capsicum germplasm based on microsatellite and random amplified microsatellite polymorphism markers. Physiol. Mol. Biol. Plants 2013, 19, 575-586. [CrossRef]

38. Camacho-Pérez, L.; Martínez-Castillo, J.; Mijangos-Cortes, J.O.; Ferrer-Ortega, M.M.; Baudoin, J.P.; Andueza-Noh, R.H. Genetic structure of Lima bean (Phaseolus lunatus L.) landraces grown in the Mayan area. Genet. Resour. Crop. Evol. 2018, 65, 229-241. [CrossRef]

39. Martínez-Castillo, J.; Colunga-García Marín, P.; Zizumbo-Villarreal, D. Genetic erosion and in situ conservation of Lima bean (Phaseolus lunatus L.) landraces in its Mesoamerican diversity center. Genet. Resour. Crop. Evol. 2008, 55, 1065-1077. [CrossRef]

40. González, E.T.; Casanova, C.C.; Gutiérrez, L.P.; Torres, L.T.; Contreras, F.M.; Peraza, S.S. Chiles cultivados en Yucatán. In Biodiversidad y Desarrollo.Humano en Yucatán; Durán, R., Méndez, M., Eds.; CICY CONABIO, SEDUMA: Yucatán, Mexico, 2010; pp. 342-344.

41. Baral, J.B.; Bosland, P.W. Unraveling the species dilemma in Capsicum frutescens and C. chinense (Solanaceae): A multiple evidence approach using morphology, molecular analysis, and sexual compatibility. J. Amer. Soc. Hort. Sci. 2004, 129, 826-832. [CrossRef]

42. Ince, A.G.; Karaca, M.; Onus, A.N. Genetic relationships within and between Capsicum species. Biochem. Genet. 2010, 48, 83-95. [CrossRef] [PubMed]

43. Soria-Fregoso, M.; Trejo-Rivero, J.A.; Tun-Suárez, J.M.; Terán-Saldivar, R. Paquete TecnolóGico Para la Producción de Chile Habanero, 3rd ed.; SEP, DGETA ITA-2: Yucatán, México, 2002; p. 430.

44. Pickersgill, B. The archeological record of chili peppers (Capsicum spp.) and the secuence of the domestication in Peru. Amer. Antiq. 1969, 34, 54-61. [CrossRef]

45. Tanksley, S.D.; McCouch, S.R. Seed banks and molecular maps: Unlocking genetic potential from the wild. Science 1997, 277, 1063-1066. [CrossRef]

46. Hanáček, P.; Vyhnánek, T.; Rohrer, M.; Cieslarová, J.; Stavělíková, H. DNA polymorphism in genetic resources of red pepper using microsatellite markers. Hort. Sci. 2009, 36, 127-132. [CrossRef]

(C) 2019 by the authors. Licensee MDPI, Basel, Switzerland. This article is an open access article distributed under the terms and conditions of the Creative Commons Attribution (CC BY) license (http://creativecommons.org/licenses/by/4.0/). 